УдК 342.5:316.422:343.35:342.6

DOI https://doi.org/10.32837/pyuv.v0i2(27).182

О.Л. Макаренков

кандидат юридичних наук, доцент, доцент кафедри історії і теорії держави та права, заступник декана з міжнародної діяльності юридичного факультету Запорізького національного університету

\title{
ПРАВОВІ ЗАСАДИ ЕЛІМІНАЦЇ̈ КОРУПЦІЙНИХ РИЗИКІВ ІЗ ВИКОНАВЧО-РОЗПОРЯДЧОЇ РОБОТИ ПУБЛІЧНОЇ АДМІНІСТРАЦІї В УМОВАХ ТРАНСФОРМАЦІЇ ПРАВОВОЇ СИСТЕМИ ВІДКРИТОГО СУСПІЛЬСТВА
}

Формально-юридична фіксація основ організації та функціонування органів публічної влади на конституційному рівні в усіх країнах світу, окрім власне правових ідей, передбачає акценти на політичних, економічних чи інших соціально детермінованих проблемах, вирішення яких найбільш актуальне для нації на конкретно історичному етапі її розвитку. Наприклад, у розділах 27 і 28 ст. 2 Конституції Республіки Філіппіни вказано, що держава підтримуватиме чесність та доброчесність на публічній службі та вживає позитивних та ефективних заходів проти підкупу (хабарів) та корупції. Керуючись раціональними умовами, відповідно до закону, держава приймає та проводить політику повного публічного розкриття змісту усіх своїх дій, що стосуються суспільних (публічних) інтересів [1]. Для України та низки інших держав не менш важливо мінімізувати корупцію, проте конституційно-правових норм відповідного змісту у них немає. Ідеї, норми-принципи, норми-декларації антикорупційного змісту існують у таких країн на рівні доктрини і природного права, а також отримують своє матеріальне і процесуальне розгортання традиційно у лоні норм кримінально- і адміністративно-правового характеру. Доцільно було б антикорупційну ідею чітко виписати в конституції, наприклад, під час останніх змін до неї в Україні 02.06.2016 р. або внаслідок перетворень основного закону держави, які обіцяє здійснити політична сила, що отримала президентські повноваження і більшість місць у парламенті України у 2019 р., хоча такого наміру ця сила ще не визначила. Водночас питання політично і практично залишається актуальним для осмислення та вирішення не тільки на конституційно-правовому рівні, але й у межах інших галузей права, де формально-юридично зумовлені корупційні ризики провокують недоброчесну поведінку публічної влади, зокрема й iї виконавчої гілки влади.

Мета статті - розкрити правові засади елімінації корупційних ризиків із виконавчо-розпорядчої роботи публічної адміністрації.

Теоретико-правові та галузеві юридичні проблеми ефективної й доброчесної роботи публічної адміністрації, її виконавчо-розпорядчої діяль- ності, нейтралізації в ній корупційних ризиків та низки суміжних питань грунтовно розкриті у працях українських вчених, а саме: В.Б. Авер'янова, С.К. Бостана, О.В. Гавриленка, С.Д. Гусарєва, П.В. Діхтіевского, М.І. Козюбри, Т.О. Коломоєць, В.В. Ладиченка, О.Д. Тихомирова, M.I. Хавронюка та інших. Цим проблемам приділили увагу також вчені з Республіки Білорусь, Російської Федерації та інших країн: О.С. Вірлєєва-Балаєва дослідила принцип поділу влади в системі правових обмежень державної влади, Л.М. Володіна - питання поділу влади і прав людини, М.В. Геворкян - витоки теорії поділу влади, В.М. Дубовицький - вдосконалення системи органів виконавчої влади в Республіці Білорусь, B.В. Гончаров - принципи організації і діяльності органів державної влади у РФ, О.В. Карелін - конституційно-правовий механізм реалізації принципу поділу влади в умовах російського федералізму, Б.3. Мільнер розкрив принципи організації і управління в органах виконавчої влади держави, О.С. Мінченко - контрольно-наглядові функції та державні послуги, М.Ф. Чудаков - співвідношення повноважень та інші принципи державної організації та діяльності: принцип стримування и противаг за Конституцією Республіки Білорусь тощо. Незважаючи на посилену увагу вчених до проблем виконавчої гілки державної влади, аспекти уникнення й видалення корупційних ризиків задля її доброчесності в умовах трансформацій публічного права відкритого громадянського суспільства залишилися неглибоко дослідженими. Тому тема нашої роботи актуальна.

На відміну від парламенту і суду, виконавча влада найбільш безпосередньо спілкується з населенням всіх прошарків і на всіх рівнях. Ефективність діяльності апарату управління значно зростає, коли всі основні сторони його складної діяльності врегульовані правом, коли його працівники широко використовують досягнення науки і техніки в цілях наукової організації управлінської праці, а також керуються публічними інтересами, виявляючи на роботі виключно свої чесноти [2, с. 87], не потураючи своїм порокам й не спокушаючись на хабарі та інші прояви корупції. Це вимагає детальних правових норм, які 
забезпечують ще на етапі їхнього відбору на відповідні посади в органах публічної адміністрації визначення належної кваліфікації і доброчесності в потенційних чиновників. Належне правове урегулювання таких і тісно пов'язаних із ними питань покликані запобігти корупції шляхом елімінації корупційних ризиків - сукупності умов та факторів, які закладені в системі державного управління та визначають можливість виникнення корупційної поведінки і створюють небезпеку настання негативних наслідків для життево важливих інтересів особистості, суспільства, держави [3, с. 93], у т. ч. під час надання адміністративних послуг, забезпечення її якості та реалізації покладених на публічну владу завдань, програм і планів розвитку, а також інших подібних проектів. В українському законодавстві корупційний ризик визначено як ймовірність того, що відбудеться подія корупційного правопорушення чи правопорушення, пов'язаного з корупцією, яка негативно вплине на досягнення органом влади визначених цілей та завдань (аб. 5 п. 2) [4].

Оцінка корупційних ризиків відбувається, щонайменш, на двох рівнях публічного адміністрування: а) нормативно-правового регулювання відповідних видів чи сфер діяльності (зважування ризиків у НПА та/або їх проектах); б) правозастосування - фактичних процесів проведення такої діяльності, зокрема як компонент у реалізації контрольних повноважень уповноважених органів чи посадових осіб, включно з використанням специфічних управлінських засобів, із метою виявлення відповідних корупційних практик, поведінки. Застосування відповідних методів оцінки на етапі нормопроектування дає змогу попереджати виникнення інституційних передумов корупційних деформацій в адміністративних процедурах. У цій сфері накопичено найбільший досвід щодо розробки методик оцінки корупційних ризиків [5, с. $113 ; 6$, с. 13]. А ось найбільше корупційних ризиків виникає вже на стадіях виконавчо-розпорядчої роботи (управління) - видання актів застосування норм права, які є підставою для виникнення, зміни і припинення правовідносин. Управління в будь-якій сфері життя суспільства виражається в сукупності правових норм, які описують механізми швидкого створення правильних рішень як у питаннях стратегії, наприклад, ефективності форми власності на землю, виробничі потужності та інші матеріальні ресурси, так і тактики. Управлінським питанням також є здатність виконавчої влади держави забезпечувати максимальне використання досягнень кожної галузі в усіх інших напрямах розвитку. Наприклад, наукові відкриття, інформаційні технології, інфраструктурні об'єкти одночасно є окремими предметами управління і частиною будь-якого іншого предмета публічного адміні- стрування. Відповідно, якщо зміст всіх напрямів роботи чиновників тісно перетинається, то так само збільшуються та ускладнюються корупційні ризики, їхня профілактика стає сумнівною. Тому важливе розуміння природи і змісту предмета напрямів роботи публічної адміністрації, а саме: 1) достатності підстав для виокремлення функцій по предметній ознаці за ознаками критичної маси однорідних відносин і суміжних питань як всередині, так і поза межами держави (за критеpiєм юридико-географічного простору роботи); 2) суб'єктно-об'єктної дистанції функції - оперативного здійснення чиновниками перших ступенів ієрархічної структури виконавчої влади i/або при безпосередньому контакті з населенням на дистанції, з кабінету; 3) темпоральної основи професійного правозастосування та інших видів управління - урахування ступеня сталості роботи чи актуальності й тривалості тимчасового характеру завдань, трансформацій тимчасових (еволюційних) [7, с. 176] завдань у постійні. Це відображає здатність виконавчої влади пристосувати свій апарат управління і примусу до належного виконання нових завдань, а також можливості враховувати відмінності процесів розвитку суспільного життя, його рух у часі, поєднання процесів відтворення одних елементів суспільних відносин і зміни інших, за умов раціонального використання публічних ресурсів і досягнення максимального ефекту для публічного інтересу.

Добрі знання предмета функціонального навантаження публічної адміністрації тільки зі щирою волею застосувати ці знання доброчесним способом гарантують уникнення корупційних ризиків. Вольовий аспект втілений у методах роботи, а саме: примусі і стимулюванні до добровільного виконання норм права, за ознакою ініціатора рішення про необхідність діяти/ утримуватися від дій відповідно до норм права і відповідальності за таке діяння. Тут ініціатива буде означати зародження, формування вольового акту, який спрямований на виконання норми права, і реалізацію цього акту волі. Відповідальність волі суб'єкта права означатиме органічну сполуку нового дії (бездіяльності) з попередніми і наступними актами прояви волі (діяннями), які об'єднані єдиною метою соціального прогресу, в тому числі повноцінної реалізації прав людини та суспільства. Теоретично, беручи до уваги ці логічні взаємозв'язки, диспозитивним (добровільним) методом роботи публічної адміністрації залишається правотворчість і акти застосування права, результати яких виконують добровільно тільки тоді, коли переконані в їхній істинності i/або вірять в авторитет посадової особи i/або колегіального суб'єкта публічної адміністрації. Icтинність норми права і підтверджений практикою авторитет - джерело натхнення, ресурс держави 
iз заохочення громадян та застосування до них методу договірного регулювання. Основою такої юридичної та управлінської адекватності стають чесноти чиновників як результат їхньої духовності, порядності. У цьому разі потреби застосувати інструменти вмовляння i/або примусу зникають, але перманентно актуалізуються щодо правопорушників, у т. ч. під видом рекомендацій, тобто орієнтації на конкретний варіант поведінки або дій, бажаних із точки зору держави й відкритого суспільства. Однак у реальному житті перманентні недосконалість (застарілість, надмірна ускладненість, неоднозначність, оціночність та ін.) законодавства та соціальна неоднорідність потреб, інтересів, наявних ресурсів, зовнішніх умов та інших життєвих фактичних обставин як на рівні органів виконавчої влади держави, так i серед пересічних громадян робить стандарти правової системи відкритого суспільства нормами-деклараціями, до яких це суспільство прагне, створюючи сприятливе тло для широкого використання методів примусу публічною адміністрацією, парною категорією якого стають корупційні ризики. При цьому такі ризики зростають там, де збільшується вага публічного примусу для повноцінної реалізації прав людини та інших суб’єктів суспільних відносин, який, як відомо, завжди має нормативно не визначену частку дискреції та низку інших перманентно не вирішуваних проблем iз належним процесуально-правовим унормуванням, відповідно до принципу верховенства права. На важливості усвідомлення праксеологічних i онтологічних його зв'язків наголошують судді та вчені, зазначаючи, що ідея верховенства права охоплює не тільки змістовний аспект (правового відношення між людиною і державою на засадах визнання людини вищою соціальною цінністю), але й процедурний аспект, який базується на вимогах відповідності правотворчої та правозастосовної практики певним стандартам, як-от: заборона зворотної дії закону, вимога ясності та несуперечності закону; вимога щодо однакового застосування закону; застосування покарання виключно на підставі закону та ін. [8, с. 10]. Адже, маючи величезну кількість працівників, публічна адміністрація на чолі з Президентом та його довіреними топ-радниками не в змозі контролювати доброчесність діянь їх усіх. У зв'язку із цим вагомим є те, що за таких умов неналежного контролю й безкарності наявні в чиновників публічні повноваження - гарна основа для зловживань [9, с. 337$]$.

3'ясування сутності цих проблемних питань яскраво ілюструє характеристика корупційних ризиків у сфері діяльності правоохоронних органів, до яких зараховуємо чинники зі структури правового регулювання доброчесності та економічних відносин відповідними інститутами адміністративного ікримінального законодавства: 1) передчасна лібералізація адміністративного, фінансового, кримінального, кримінально-процесуального та інших галузей законодавства; відсутність, нерозвиненість, колізійність та інші вади антикорупційного законодавства - низька якість законів, їх неузгодженість та недосконалість контрольно-наглядової системи, нечіткість процедур правозастосовної діяльності. Процеси реформування основ економіки та економічної практики суттєво випереджають їх законодавче забезпечення, наприклад, приватизація за відсутності відповідного законодавчого регулювання, контролю та інститутів відповідальності, відсутня відповідальність за податкові правопорушення, частка тіньової економіки суттєва; 2) фінансові/економічні кризи і політична нестабільність; втрата морально-етичних установок, пов'язаних із майновою нерівністю громадян, суттєвим майновим розшаруванням населення й зубожінням його широких верств - пенсіонерів, публічних службовців, що схиляє їх до хабарництва, та інших; 3) розпорошення повноважень суб'єктів системи контролю за умови відсутності єдиного органу державного контролю, обмеження їхніх повноважень, у тому числі з використанням інститутів адміністративного і судового оскарження; 4) неконтрольовані процеси правомірності цілей створення й функціонування організацій, зокрема підприємницького змісту, які фактично займаються фіктивним підприємництвом без угод, реально наповнених господарською діяльністю, для переведення в готівку грошей підприємств реального підприємництва, які таким чином приховують свої прибутки і ухиляються від їхнього оподаткування; 5) неспроможність правоохоронної і податкової систем ефективно протидіяти правопорушенням у сфері економіки та корупції; 6) низький рівень матеріального забезпечення посадових осіб правоохоронних органів, особливо нижньої й середньої ланок, що призвело до дискредитації, непрестижності державної служби, службових апатії, деформацій, фрустрації, крадіжок публічних ресурсів в умовах неможливості досягти успіху в житті публічними способами, забезпечивши собі і своїй сім’ї конституційно гарантовані відтворення й розвиток, й втрати довіри від громадян; 7) відсутність системного підходу у боротьбі зі злочинністю у сфері економіки і корупції й щирого бажання цього у вищого керівництва держави та великих підприємців, підміна її епізодичними й показовими кампаніями, що зумовило виникнення безкарності корупціонерів на всіх рівнях, насамперед, чиновників керівного складу центральних органів публічної влади та органів місцевого самоврядування; 8) відсутність достатньо вичерпних норм, які були б безпосередньо спрямовані на профілактику й зниження рівня правопорушень у 
сферах оподаткування, витрат публічних фінансів та інших сферах, високого корупційного ризику [5, с. 133-135].

Корупція насправді порушує право людини: право на свободу, яке може бути реалізоване лише в громадянському суспільстві, де влада надає блага відповідно до чинних законів, загальних для всіх і спрямованих на загальне благополуччя [10, с. 484]. Передумови забезпечення людської свободи й профілактики корупційних ризиків у сфері публічного адміністрування вбачаються у формуванні важливого для націєтворення й економічного фундаменту верховенства права середнього класу через механізми фіскальної політики (збалансування податкового навантаження, адміністрування бюджетних надходжень) і політики розподілу доходів публічних бюджетів та фондів (яка б стимулювала громадян до соціально корисної активності й виключала б різку поляризацію статків серед них), систем освіти (підвищення якості освіти, забезпечення зв'язку університетської освіти з практичним набуття навичок та ін.) й іншого духовнокультурного розвитку. За таких умов можливості працевлаштування у публічній адміністрації та інших органах державної влади високоосвічених й доброчесних фахівців зростають, елімінуючи корупційні практики непотизму, клієнтелизму (лат. clientēla, p. -le; фаворитизму, кумівства) і тому подібні роботи «потрібних людей» із «вигідними знайомствами та зв'язками» [11, с. 335].

Враховуючи вищенаведені характеристики корупційних ризиків, успішне функціонування публічної адміністрації у відкритому для прогресу на основі доброчесності суспільстві передбачає їхню елімінацію шляхом кореляції власних діянь і нормативно-правової основи роботи відповідно до низки правових принципів, які враховують політичну і правову унікальність виконавчої влади в механізмі публічної влади: 1) природно-правової вимірності управління й правотворення, контролю і примусу. Це означає, що розроблені й ухвалені публічною адміністрацією правові підзаконні акти реально забезпечують рівні й справедливі умови відтворення, накопичення, обліку та розподілу благ. Така адміністрація повноцінна, ієрархічно замкнена технократична система [12, с. 282-283], що складається з професійних й порядних чиновників, які знають, розуміють й впроваджують у своїй роботі найкращі людські чесноти і правові стандарти; 2) зумовленості роботи публічної адміністрації і кожного їі окремого чиновника потребами людини і соціального прогресу; 3) врівноваження владою парламенту і судів [13, с. 57]. Поділ повноважень вимагає від судової влади перевіряти дії президента та інших посадових осіб органів виконавчої гілки державної влади, коли вони суперечать законодавчим чи конституційним положенням, для посилен- ня правової законності виконавчого процесу та захисту від зловживань відповідно до ідеї справедливості, у тому числі в умовах воєнного часу [14, с. 150]. Схвалені парламентом акти лише в загальних рисах визначають і підкреслюють загальнообов'язкові правила поведінки. Деталізацією цих правил займається уряд та його система органів в актах їхньої правотворчості (постанов) і правозастосування (роз'яснень, повідомлень та листів). Також уряд взаємодіє із парламентом, користуючись своїм правом законодавчої ініціативи. Він домагається від парламенту схвалення внесених ним законопроектів у потрібній йому редакції, що фактично усуває депутатів парламенту від відповідальності за результати його соціально корисної дії та ефективності, перекладаючи її на публічну адміністрацію [15, с. 243]. При цьому природно, що уряд залишається підзвітним парламенту за свої акти дії та бездіяльність. Кожного міністра чи іншого керівника органу виконавчої гілки публічної влади сприймають як відповідального за свої власні рішення та за всі дії очолюваного й контрольованого ним відомства [15, с. 228]. Парламентський контроль над президентом держави в реальному житті не істотний, стосується, як правило, здійснення президентом злочинів. 3 огляду на владу президента країни, навіть якщо він вчинить злочин, то ймовірність доведеності складу злочину і притягнення до кримінальної відповідальності мізерно мала, тому що його повноважень часто цілком достатньо для того, щоб перешкодити цьому в перспективі будь-якого відрізку часу; 4) незалежність від волі всередині публічної адміністрації - формально і/ або від поглядів на сутність та зміст управлінської роботи [16, с. 6-7]; 5) єдність системи органів публічної адміністрації, хоча кожен із них може мати відмінні один від одного правові позиції. «Виконавча публічна влада унітарна», усі їі компоненти, структури конституюють різні підходи до вирішення одних й тих самих питань у канві різних предметів та напрямів діяльності та зумовлених цим змістом повноважень й відповідальності [16, с. 5]; 6) антикорупційної стресостійкості - майстерності й доброчесності управління i збереження ефективності роботи при будь-яких спокусах задовольнити власний приватний інтерес за рахунок публічних інтересів, а також навантаженнях політичного, військового i/aбо 3 іншим змістом, у тому числі в умовах загрози національній безпеці, крайньої необхідності; 7) універсальності - охоплення всіх правових відносин; 8) професійної та добропорядної ефективності - виявлення під час публічного адміністрування своїх компетентностей, їхнього розвитку та інших людських чеснот із метою максимального задоволення інтересів громадян, відповідно до загальнолюдських природно-правових цінностей. 
Таким чином, корупційні ризики у сфері публічного адміністрування являють собою чинники (передумови) онтологічно об'єктивного й суб'єктивного характеру, що за несприятливих для існування доброчесності обставин перетворюються на умови для корупції чиновників. Відповідно, доброчесне в умовах несуттєвого потенціалу корупційних ризиків виконання публічною адміністрацією функцій у відкритому суспільстві передбачає її відповідність спеціальним правовим принципам (ознакам): природно-правовій вимірності управління й правотворення, контролю і примусу; зумовленості роботи потребами людини і соціального прогресу; збалансування владою парламенту і судів; незалежністю внутрішніх структур одна від одної у питаннях змістовного наповнення своєї діяльності, відповідно до законодавчо визначеної компетенції; єдності системи органів; антикорупційної стресостійкості; універсальності вирішення усіх підвідомчих питань у рамках країни та поза нею щодо власних громадян та інших цінностей; професійної та добропорядної ефективності. Ступінь фактичної відповідності публічної адміністрації цим та іншим правовим засадам елімінації корупційних ризиків з її професійної діяльності в умовах трансформації правової системи відкритого суспільства являє собою пряму пропорційну залежність зі станом відкритості останнього. При цьому сама наявність знань і високоякісного законодавства, яке відповідає правовим стандартам відкритих суспільств, має обов'язково супроводжуватись реалізацією цих знань і норм у діях всіх органів виконавчої гілки влади держави, інакше нація буде неминуче слабшати до тих пір, поки не зникне як єдине ціле соціальне утворення. Корисно мати і застосовувати ті конституційні моделі урядового правління, що найбільш ефективні для конкретного історичного моменту часу та засновані на ідеї верховенства права, зокрема й незмінності фундаментальних положень, які стосуються прав людини і загальноправових питань устрою публічної влади. Водночас специфічними рисами таких моделей, які зумовлюють доброчесну, професійну та, зрештою, ефективну роботу публічної адміністрації стають конституційні положення деталей компетенції, призначення членів уряду, голів місцевих органів виконавчої гілки влади держави, співвідношення повноважень центральної і місцевої публічної влади (питання децентралізації публічних коштів, повноважень та відповідальності) та інші норми, трансформації яких об єктивно зумовлені потребами забезпечення прав людини і сталого розвитку суспільства. Вони можуть бути найбільш прийнятними для застосування в одні періоди розвитку суспільства і абсолютно неприйнятними в інші періоди розвитку. Роль парламенту та муніципальної влади у всіх вищеописаних та суміжних взаємозв'язках доброчесності-права подальші напрями дослідження.

\section{Jimepamypa}

1. The Constitution of the Republic of the Philippines, ratified: February 2, 1987. URL: https://www.officialgazette.gov.ph/constitutions/ 1987-constitution/.

2. Лунев А.Е. Право и эффективность управления. Москва : «Юрид. лит.», $1973.88 \mathrm{c.}$

3. Дмитрієв Ю.В. Причини виникнення корупційних ризиків у системі державного управління. Інвестиції: практика та досвід. 2016. № 4. С. 92-95.

4. Методологія оцінювання корупційних ризиків у діяльності органів влади, затв. рішенням НАЗК 02.12.2016 p. № 126. URL: https://zakon.rada.gov.ua/ laws/show/z1718-16.

5. Івасенко С.М. Запобігання та протидія корупції в правоохоронних органах: організаційно-управлінський аспект : дис. ... канд. наук 3 держ. управ. : 25.00.01. Київ, 2015. 199 с.

6. Москвичева А.И. Борьба с коррупцией в странах с переходной экономикой. Борьба с преступностью за рубежом. 2007. № 3. С. $13-26$.

7. Курашвили Б.П. Очерк теории государственного управления : монография. Москва : Наука, 1987. 296 с.

8. Фулей Т.І. Застосування практики Європейського суду з прав людини при здійсненні правосуддя: наук.-метод. посібник для суддів. 2-ге вид. випр., допов. Київ, 2015. 208 с.

9. Khan F.R. Ensuring Government Accountability During Public Health Emergencies. Harvard Law \& Policy Review. 2010. Vol. 4. Iss. 1. P. 319-338.

10. Spalding A.B. Freedom from corruption: the new human right? New Voices: Human Rights. 2013. Vol. 107. P. 483-486.

11. Лозова Г., Клименко В. Історичні передумови формування та розвитку середнього класу в США: уроки для України. США у сучасному світі: політика, економіка, право, суспільство : збірник матеріалів II міжн. наук.-практ. конф. Ч. 1, м. Львів, 15.05.2015 p. / упоряд. Калитчак Р.Г., Зазуляк 3.М. Львів : Центр американських студій ФМВ ЛНУ ім. І. Франка, 2015. C. $329-336$.

12. Cunha P.F. Repensar a politica: ciencia \& ideologia / Paulo Ferreira da Cunha. 2.a edição revista e atualizada. Coimbra: Almedina. 2007. $496 \mathrm{p}$.

13. Marques M.R. Introducao ao direito ; volume I, 2.a edicao. Coimbra : Almedina, 2007. $482 \mathrm{p}$.

14. Oberlander N. Executive process: the due process of executive citizen targeting by the Commanderin-Chief. National security law journal. 2013. Vol. 1. Iss. 1. P. 124-150.

15. Johari J.C. New Comparative Government. New Delhi : Lotus Press, 2006. 460 p.

16. Clement P.D. Theory and Structure in the Executive Branch. The University of Chicago legal forum. 2011. Vol. 2011. Iss. 1. P. 1-18.

\section{Анотація}

Макаренков О. Л. Правові засади елімінації корупційних ризиків із виконавчо-розпорядчої роботи публічної адміністрації в умовах трансформації правової системи відкритого суспільства. - Стаття.

У статті досліджено правові засади елімінації корупційних ризиків із виконавчо-розпорядчої роботи публічної адміністрації в умовах трансформації пра- 
вової системи відкритого суспільства. Встановлено, що доброчесне виконання публічною адміністрацією функцій у відкритому суспільстві передбачає її відповідність природно-правовій вимірності управління й правотворення, контролю і примусу, зумовленість роботи потребами людини і соціального прогресу, збалансованість владою парламенту і судів, незалежність внутрішніх структур одна від одної у питаннях змістовного наповнення своєї діяльності, відповідно до законодавчо визначеної компетенції, єдність системи органів, антикорупційну стресостійкість, універсальність вирішення усіх підвідомчих питань у рамках країни та поза нею щодо власних громадян та інших цінностей, професійну та добропорядну ефективність. Підкреслено, що сама наявність знань і високоякісного законодавства, яке відповідає правовим стандартам відкритих суспільств, має обов'язково супроводжуватись реалізацією цих знань і норм у діях всіх органів виконавчої гілки влади держави, інакше нація буде неминуче слабшати до тих пір, поки не зникне як єдине ціле соціальне утворення. Підсумовано, що уникненню корупційних ризиків та зменшенню їхнього потенціалу сприяє використання тих конституційних моделей публічного адміністрування, що найбільш ефективні для конкретного історичного моменту часу та засновані на ідеї верховенства права, зокрема й незмінності фундаментальних положень, які стосуються прав людини $і$ загальноправових питань устрою публічної влади.

Ключові слова: верховенство права, доброчесність, конституція, корупція, правозастосування, примус, публічна адміністрація, ризики.

\section{Summary}

Makarenkov $O$. L. The legal basis for the elimination of corruption risks from executive work of the public administration in the conditions of the legal system transformation of an open society. - Article.

The article reveals the legal principles of eliminating corruption risks from public administration's executive work in the context of the legal system transformation of an open society. It is established that corruption risks in the sphere of public administration are factors (prerequisites) of an ontologically objective and subjective character, which, under unfavorable circumstances of virtue of officials, turn into conditions for corruption. At the same time, the virtuous performance by public administration of functions in an open society implies its compliance with the natural and legal dimension of governance and lawmaking, control and coercion; conditionality of work for human needs and social progress; balancing the power of parliament and the courts; the independence of internal structures from one another in matters of meaningful fulfillment of their activity, in accordance with legally determined competence; unity of the organ system; anticorruption stress; the universality of all subordinate matters within and outside the country with respect to one's own citizens and other values; professional and decent efficiency. It is emphasized that the very availability of knowledge and high quality legislation, which corresponds to the legal standards of open societies, must necessarily be accompanied by the implementation of this knowledge and norms in the actions of all executive bodies of the state power, otherwise the nation will inevitably weaken until it disappears as a whole social formation.

It is emphasized that the preconditions of ensuring human freedom and prevention of corruption risks in the sphere of public administration are seen in the formation of the middle class. This is important for the nationalization and economic foundations of the rule of law. These values are implemented through fiscal policy mechanisms and a fair distribution of public budgets and funds; system of education and other spiritual and cultural development of people. Under these conditions, employment opportunities in the public administration and other public authorities are increased by highly educated and virtuous professionals, eliminating the corrupt practices of nepotism, clientelism and the like.

It is concluded that the avoidance of corruption risks and the reduction of their potential is facilitated by the use of those constitutional models of public administration that are most effective for a particular historical moment and based on the idea of the rule of law, in particular, the fundamental principles of human rights and general law are unchanged. At the same time, the specific features of such models that determine the integrity, professional and ultimately effective work of the public administration are the constitutional provisions of the details of competence, the appointment of members of the government, heads of local executive branches of state power, the ratio of powers of central and local public authorities, and accountability) and other norms whose transformations are objectively conditioned by the need for human rights and the sustainable development of society. They may be most acceptable for use in one period of society and absolutely unacceptable in other periods of development.

Key words: rule of law, integrity, constitution, corruption, law enforcement, coercion, public administration, risks. 